Jurnal Laut Khatulistiwa, Vol. 3 No. 2 (Juli, 2020), Hal. 48-54.

ISSN : 2614-6142 (Printed), 2614-8005 (Online)

http://jurnal.untan.ac.id/index.php/lk

JURNAL LAUT

KHATULISTIWA

\title{
Distribusi Sedimen Dasar di Perairan Muara Mempawah Kalimantan Barat
}

\section{Distribution Sediment of Bedload at the Estuary Waters Mempawah, West Borneo}

\author{
Aji Ansari ${ }^{*}$, Apriansyah'1, Risko1 \\ ${ }^{1}$ Laboratorium Ilmu Kelautan, FMIPA Universitas Tanjungpura, Pontianak, Indonesia \\ *E-mail : ajiansari562@gmail.com \\ Received : 5 Mei 2020 ;Accepted : 20 Juni 2020 \\ Published: 30 Juni 2020 (c) Author(s) 2020. This article is open access
}

\begin{abstract}
The research bedload sedimentary distribusion is conducted in Estuary Mempawah, from February to March 2019. The study aims to determine the size of the sedimentary grain and the bedload sedimentary distribution. The research procedure begins with the bedload sediment from 12 stations. Than measurements of oceanographic conditions such as, tides, currents and measurement of waves. The results showed that the sedimentary fraction of the sand domination with the type of clay and sandy clay sediments. Current velocity of base current dominance with a value of $0.082 \mathrm{~m} / \mathrm{s}$ and A significant wave of 0.69 meters, the tides in these waters are a type of mixed diurnal seen from Formzhal (F) number 2.46 in the waters.
\end{abstract}

Keywords : Sedimentary fraction, sediment distribution, West Borneo

\begin{abstract}
Abstrak
Penelitian distribusi sedimen dasar dilakukan di Perairan Muara Mempawah, sejak bulan Februari hingga Maret 2019. Penelitian ini bertujuan untuk mengetahui sebaran ukuran butir sedimen dan sebaran sedimen dasar perairan. Prosedur penelitian diawali dengan pengambilan data sedimen dasar dari 12 stasiun. Kemudian pengukuran kondisi Oseanografi seperti, Pasang surut, Arus dan pengukuran Gelombang. Hasil penelitian menunjukan bahwa sebaran fraksi sedimen dominasi pasir dengan jenis sedimen tanah liat dan tanah liat berpasir. Kecepatan arus dominasi arus dasar dengan nilai sebesar 0,082 $\mathrm{m} / \mathrm{s}$ dan gelombang signifikan sebesar 0,69 Meter, dengan pasang surut di perairan ini merupakan tipe campuran condong harian tunggal dilihat dari bilangan Formzhal (F) 2,46 di perairan.
\end{abstract}

Kata kunci : Fraksi sedimen, distribusi sedimen, Kalimantan Barat.

\section{Pendahuluan}

Muara Sungai Mempawah merupakan kawasan yang memilliki peran penting bagi masyarakat sekitar seperti alur masuk/keluar bagi kapal, area pertambakan ikan, serta terdapat PPI (Pangkalan Pendaratan ikan) yang difungsikan sebagai pelabuhan tempat bongkar muat ikan dan persinggahan kapalkapal (Solom et al., 2020).

Keberadaan kawasan ini sangat mendukung perekonomian masyarakat dimana mayoritas penduduk sekitar berfokus di bidang kelautan, sehingga akan meningkatkan aktivitas di wilayah perairan. Aktivitas tersebut akan berdampak terhadap kondisi kedalaman dan lebar di perairan muara Mempawah.

Muara sungai pada umumnya merupakan tempat bertemunya dua aliran massa air yang berbeda dari kawasan pesisir dan sungai (Komar, 1998). Kecepatan aliran di muara sungai sering terjadi dan mengalami perubahan ketika aliran air memasuki muara akan kehilangan energi dan semakin lambat. Aliran air yang mengalami perlambatan akan menyebabkan pengendapan sedimen dimuara 
Jurnal Laut Khatulistiwa, Vol. 3 No. 2 (Juli, 2020), Hal. 48-54.

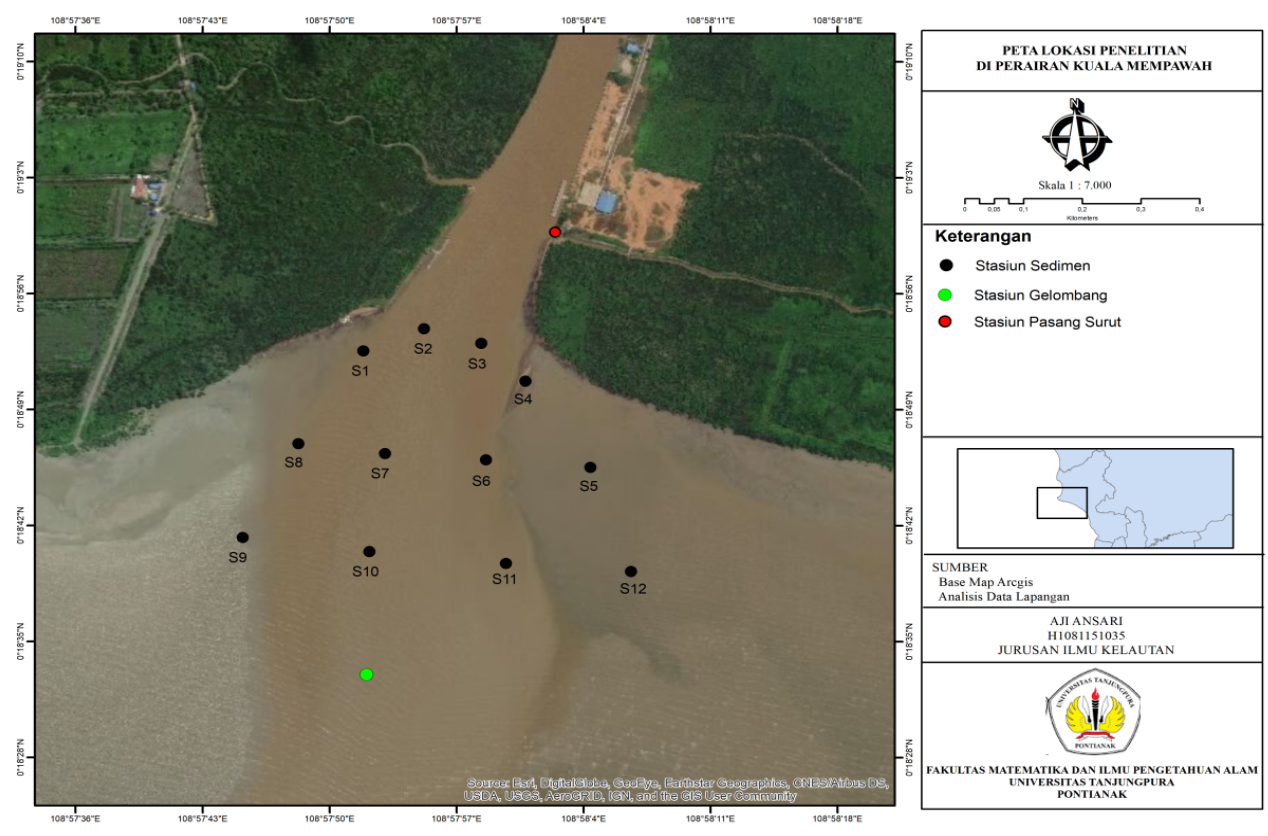

Gambar 1. Peta perairan Muara Kuala Mempawah yang menjadi daerah penelitian, terdapat titik pengukuran pasang surut, pengambilan sampel sedimen dan arus serta titik pengukuran gelombang.

sungai sehinga terjadi sedimentasi dimulut muara sungai dan terjadi perubahan morfologi muara sungai Mempawah (Pangestu et al., 2020).

Sedimentasi merupakan proses perpindahan (terdeposisi) material sedimen yang kemudian mengalami pengendapan. Pada umumnya kawasan muara sungai adalah tempat terjadinya penumpukan sedimen yang dipengaruhi oleh faktor kondisi hidrooseanografi di peraian. Faktor tersebut menjadi media transport material sedimen seperti arus, gelombang dan pasang surut (Cristine et al., 2014). Sedimentasi yang terjadi secara terus menurus akan mengakibatkan penumpukan sedimen dimuara sungai Mempawah sehingga akan mengalami pengurangan kedalaman.

Penelitian mengenai sedimentasi merupakan suatu hal yang penting terutama pengetahuan tentang jenis sedimen dan sebaran sedimen dasar sebagai pemasok utama terjadinya perubahan kedalaman di kawasan muara. Pendekatan menggunakan data sedimen dasar dengan melihat kondisi Oseanografi perlu dilakukan. Oleh karena itu tujuan dari tulisan ini adalah mempelajari distribusi sedimen dasar di muara Sungai Mempawah.

\section{Metode}

\subsection{Waktu dan Lokasi Penelitian}

Penelitian ini dilakukan di muara sungai Mempawah, Kalimantan Barat (Gambar 1). Pengambilan data dilakukan pada bulan Februari hingga Maret 2019. Pengambilan sampel sedimen dilakukan dengan metode Purposive sampling mengacu pada Yudhowati et al. (2012). Pengambilan sampel dilakukan dengan menggunakan sedimen grab selama 1 hari dari 12 titik sampling. Pengamatan pasang surut dilakukan menggunakan palm pasut selama 30 hari dengan interval 1 jam (Solom et al., 2020). Pengukuran arus dilakukan menggunakan Flowmeter selama 1 hari dengan 12 titik pengukuran (Gambar 1). Pengukuran gelombang dilakukan selama 3 hari, 4 kali pencatatan dengan interval 1 jam dari 51 data lembah dan puncak gelombang perharinya berdasarkan kondisi lokasi peneliitian (Gambar 1).

\subsection{Analisis Data}

Pengolahan sampel sedimen menggunakan metode prosedur penetapan tekstur tanah Agus et al. (2016). Analisis data menggunakan beberapa tahap yaitu : 


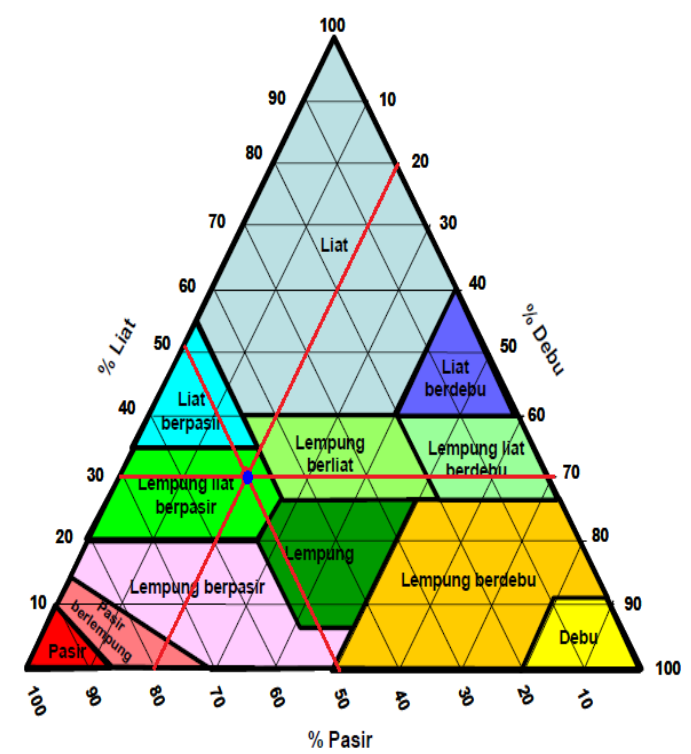

Gambar 2. Segitiga tekstur

1. Berat jenis sedimen

Dihitungan dengan persamaan :

$$
\begin{aligned}
& \mathrm{A}=\mathrm{W} 2-\mathrm{W} 1 \\
& \mathrm{~B}=\mathrm{W} 3-\mathrm{W} 4 \\
& \mathrm{C}=\mathrm{A}-\mathrm{B} \\
& \mathrm{Gs}=\mathrm{A} / \mathrm{C}
\end{aligned}
$$

Keterangan:

$\mathrm{A}=$ Berat sedimen kering

$\mathrm{B}=$ Berat sedimen basah

$\mathrm{C}=$ Berat air tanpa sedimen

Gs $=$ Berat Jenis

$\mathrm{W} 1=$ Piknometer kosong

$\mathrm{W} 2=$ Piknometer + sedimen

W3 $=$ Piknometer + sedimen + air

W4 = Piknometer + air

2. Persentase Ukuran Butir Sedimen

Dihitung persentase ukuran butir dengan persamaan :

$$
\begin{aligned}
& \mathrm{R}=\mathrm{R} 1-\mathrm{R} 2 \\
& \mathrm{~K}_{2}=\frac{a}{w} \times 100 \% \\
& \mathrm{P}=\mathrm{K}_{2} \cdot \mathrm{R} \\
& \mathrm{D}=\mathrm{K} \sqrt{L / T}
\end{aligned}
$$

Keterangan:

$\mathrm{R}=$ Koreksi pembacaan hidrometer

R1 = Pembacaan hidrometer pada sampel

$\mathrm{R} 2=$ Pembacaan hidrometer pada liquid

$a=$ Faktor koreksi hydrometer

$w=$ Massa sedimen

$\mathrm{P}=$ Garis Persentase ukuran sedimen
$\mathrm{D}=$ Diameter partikel

$\mathrm{K}=$ Konstanta

(1) $\mathrm{L}=$ Kedalaman

(2) $\mathrm{T}=$ Periode

3. Penggunaan segitiga Tekstur (USDA)

Segitiga tekstur (Gambar 2) digunakan dalam menentukan jenis sedimen setelah persentase fraksi sedimen ditentukan. Seperti fraksi lanau, lempung dan pasir.

\section{Hasil dan Pembahasan}

\subsection{Fraksi Sedimen Dasar}

Berdasarkan hasil analisis sedimen yang telah dilakukan di Labratoriun. Sedimen dasar di perairan Muara Mempawah terdapat tiga fraksi (butiran) sedimen. Fraksi sedimen lanau, lempung dan pasir, didominasi oleh pasir. Fraksi pasir memiliki komposisi persentase berkisar $21-62 \%$ dengan rata-rata $44,5 \%$. Kemudian untuk komposisi fraksi lanau 8-50\% dengan rata-rata 35,33\%. Sedangkan paling rendah yaitu fraksi lempung $20,16 \%$ dengan persentase 9-38\%. Dapat dilihat Gambar 3.

\section{Hasil dan Pembahasan}

\subsection{Fraksi Sedimen Dasar}

Berdasarkan hasil analisis sedimen yang telah dilakukan di Labratoriun. Sedimen dasar di perairan Muara Mempawah terdapat tiga 
Jurnal Laut Khatulistiwa, Vol. 3 No. 2 (Juli, 2020), Hal. 48-54.
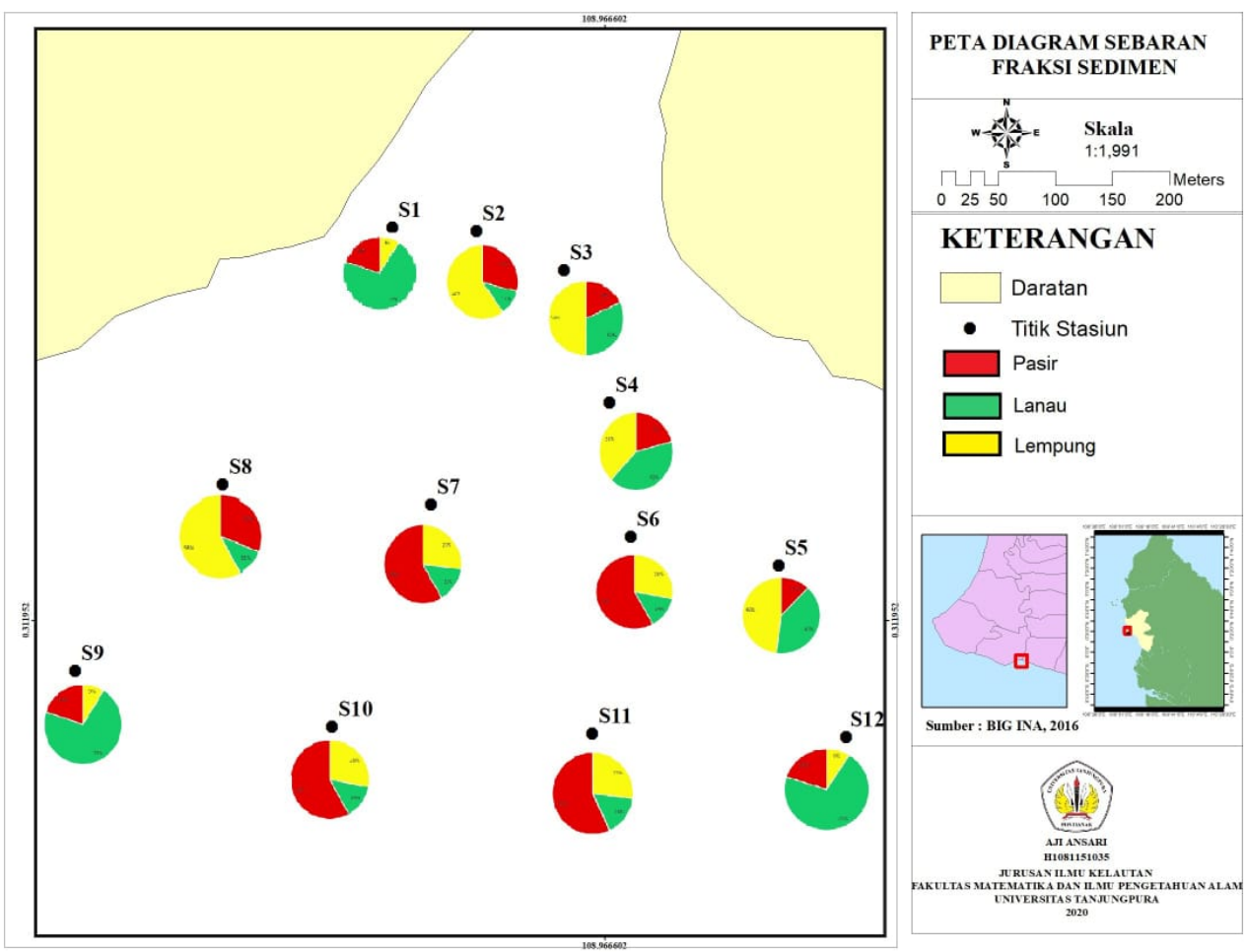

Gambar 3. Peta sebaran fraksi sedimen di perairan Muara Kuala Mempawah.

fraksi (butiran) sedimen. Fraksi sedimen lanau, lempung dan pasir, didominasi oleh pasir. Fraksi pasir memiliki komposisi persentase berkisar 21-62\% dengan rata-rata $44,5 \%$. Kemudian untuk komposisi fraksi lanau $8-50 \%$ dengan rata-rata 35,33\%. Sedangkan paling rendah yaitu fraksi lempung 20,16\% dengan persentase 9-38\%. Dapat dilihat Gambar 3.

\subsection{Distribusi Sedimen Dasar}

Sebaran sedimen dasar pada mulut muara Mempawah yang telah dianalisis berdasarkan diagram segitiga USDA, diperoleh 5 jenis sedimen. Berupa jenis lempung, tanah liat berpasir, tanah liat berlempung, campuran tanah liat berpasir, dan tanah liat pada masingmasing lokasi. Stasiun pengambilan sampel sedimen $(1,5,9$, dan 11) terdapat jenis Sedimen tanah liat berpasir. Sedangkan pada daerah stasiun $(6,7,10$ dan 11) terdapat jenis sedimen tanah liat dan pada stasiun stasiun 3 jenis sedimen lempung, 3 dan 4 terdapat jenis sedimen tanah liat berlempung serta pada daerah stasiun 4 ditemukan jenis sedimen campuran tanah liat lempung berpasir seperti dilihat pada (Tabel 1).
Daerah stasiun jenis sedimen pasir berupa tanah liat berpasir. Sedimen butiran kasar pada stasiun tersebut terdapat pada sisi garis pantai, memungkinkan adanya pengaruh dari kawasan pesisir oleh dampak abrasi dari arus dan gelombang sejajar garis pantai dalam memproses pencampuran perpindahan partikel sehingga mengendap pada stasiun tersebut. Menurut Gallagher et al. (2003) dalam Yugiswara (2017) mengkorelasikan sedimen dengan kenaikan tinggi gelombang, ketika ukuran butir sedimen semakin tinggi maka gelombang yang terjadi di daerah tersebut juga besar. Kemudian ditegaskan kembali oleh Hendromi et al. (2015) tinggi gelombang laut signifikan sangat berpengaruh terhadap angkutan sedimen. di kawasan yang memiliki gelombang laut yang tinggi umumnya memiliki ukuran butir yang kasar.

Sebaran sedimen lanau dan lempung atau tanah liat dengan jenis sedimen ukuran butir yang halus (Gambar 3) terdapat pada daerah tegak lurus aliran sungai. Berdasarkan peta analisis curah hujan dari bulan desember 2018 hingga maret 2019 menunjukan keadaan curah hujan pada daerah Kabupaten Mempawah masuk kategori intensitas curah sedang sampai dengan tinggi. Tingginya curah 
Jurnal Laut Khatulistiwa, Vol. 3 No. 2 (Juli, 2020), Hal. 48-54.

Tabel 1. Persentase dan tipe sedimen dasar di perairan Muara Kuala Mempawah

\begin{tabular}{ccccl}
\hline \multirow{2}{*}{ Titik } & \multicolumn{2}{c}{ Fraksi Sedimen (\%) } & \multicolumn{1}{c}{ Tipe Sedimen } \\
\cline { 2 - 4 } Sampling & Lempung & Lanau & Pasir & \\
\hline Lokasi 1 & 9 & 29 & 62 & Tanah liat berpasir \\
Lokasi 2 & 29 & 35 & 36 & Tanah liat berlempung \\
Lokasi 3 & 18 & 47 & 35 & Lempung \\
& & & & Campuran tanah liat \\
Lokasi 4 & 21 & 8 & 71 & berpasir \\
Lokasi 5 & 13 & 34 & 53 & Tanah liat berpasir \\
Lokasi 6 & 26 & 31 & 43 & Tanah liat \\
Lokasi 7 & 27 & 41 & 32 & Tanah liat \\
Lokasi 8 & 29 & 50 & 21 & Tanah liat berlempung \\
Lokasi 9 & 9 & 29 & 62 & Tanah liat berpasir \\
Lokasi 10 & 27 & 41 & 32 & Tanah liat \\
Lokasi 11 & 9 & 35 & 56 & Tanah liat berpasir \\
Lokasi 12 & 25 & 44 & 31 & Tanah liat \\
\hline & & & & Tanah Liat Berpasir dan \\
Rata-Rata & 20,16 & 35,33 & 44,5 & Tanah Liat \\
\hline
\end{tabular}

hujan didaerah tersebut mengindikasikan bertambahnya volume pada debit aliran sungai, sehingga menyebabkan erosi pada aliran sepanjang sungai. Hal tersebut membuat jenis sedimen dengan ukuran halus terbawa menuju muara sungai dengan bentuk sedimen tersuspensi atau melayang mengikuti pergerakan arus yang kemudian akan mengalami pengendapan setelah partikel tersebut mengalami flokulasi (flocs) (Triadmojo, 1999).

\subsection{Kondisi Hidrooseanografi}

Hasil pasang surut yang telah diolah menggunakan metode Least Square diperoleh komponen pasang surut yang digunakan untuk menentukan bilangan Formzahl dan MSL (Mean Sea Level) di perairan Muara Mempawah. Nilai MSL (Mean Sea Level) atau muka air laut rata- rata sebesar $63,6 \mathrm{~cm}$, dan bilangan Formzahl (F) 2,46 (Gambar 4) (Solom et al., 2020). Berdasarkan nilai $F$ yang diperoleh, tipe pasang surut di perairan Muara Mempawah yaitu pasang surut campuran condong ke harian tunggal. Menurut Triadmojo (2011) pasang surut jenis ini dalam satu hari terjadi satu kali pasang dan satu kali air surut, tetapi bisa terjadi dua kali pasang dan surut dengan tinggi dan periode yang berbeda.

Berdasarkan hasil gelombang yang telah diolah diperoleh tinggi signifikan (Hs) gelombang di perairan Muara Mempawah sebesar 0,69 meter dengan periode signifikan (Ts) gelombang 5,28 detik, tinggi gelombang maksimum terjadi di hari kedua pengamatan pada jam 13:50 WIB sebesar 1,11 meter dengan periode gelombang maksimum 4,7 detik, dan tinggi gelombang minimum terjadi di hari kedua pengamatan pada jam 10:45 WIB sebesar 0,41 meter dan periode gelombang minimum 4,7 detik. Dapat dilihat pada Tabel 2.

Berdasarkan hasil pengukuran arus yang telah dilakukan secara keseluruhan kecepatan. Arus dasar (Gambar 5) menunjukan bahwa perairan Kuala mempawah memiliki

Tabel 2. Tinggi dan Periode Gelombang di perairan Muara Mempawah.

\begin{tabular}{llll}
\hline Tanggal & Keterangan & H (m) & Periode \\
\hline 21-23-24 & Maksimum & 1,11 & 4,7 \\
Februari & Minimum & 0,41 & 4,7 \\
2019 & Signifikan & 0,69 & 5,28 \\
\hline
\end{tabular}


Jurnal Laut Khatulistiwa, Vol. 3 No. 2 (Juli, 2020), Hal. 48-54.

kecepatan

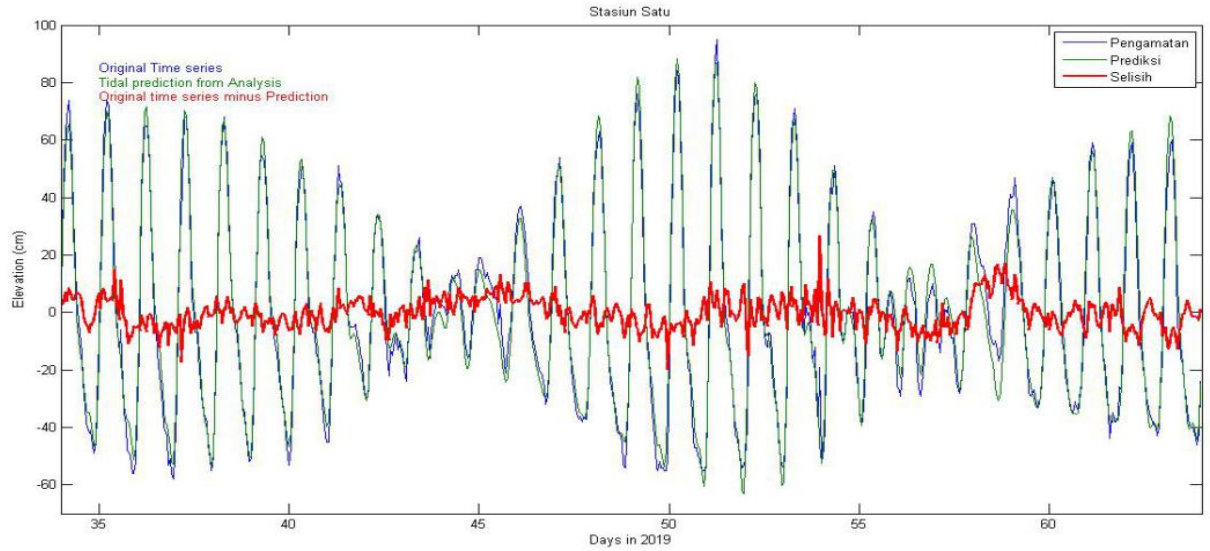

Gambar 4. Grafik pasang surut di perairan Muara Mempawah (Solom et al., 2020)

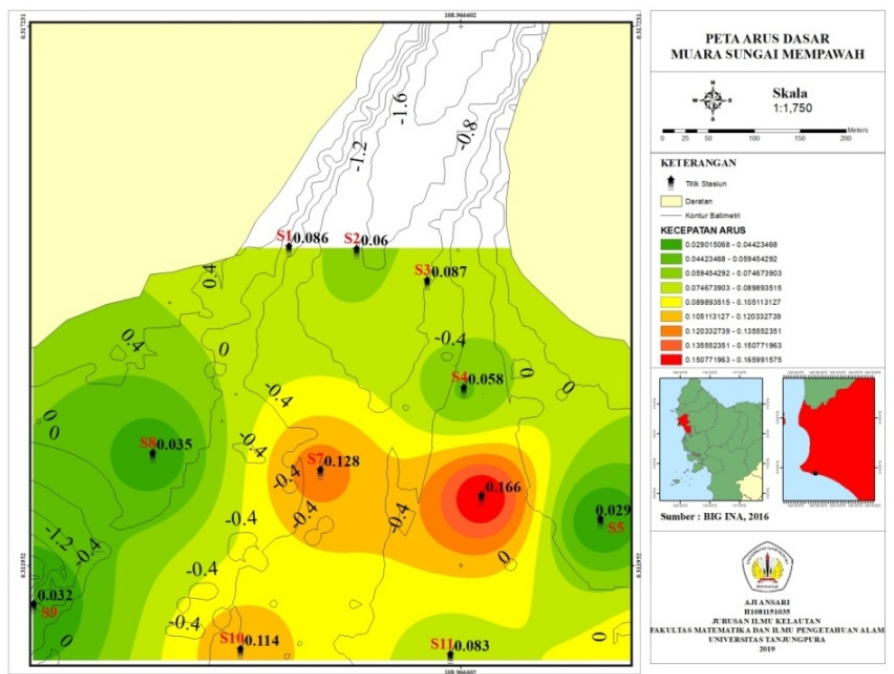

Gambar 5. Kecepatan Arus Dasar di Perairan Muara Mempawah

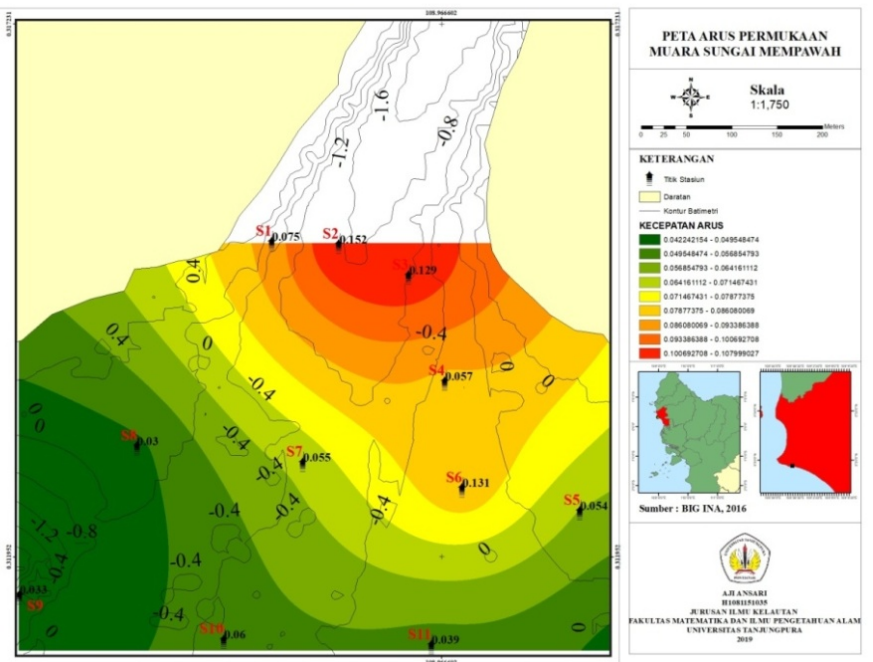

Gambar 6. Kecepatan Arus Permukaan di Perairan Muara Mempawah 
Jurnal Laut Khatulistiwa, Vol. 3 No. 2 (Juli, 2020), Hal. 48-54.

sebesar 0,082 m/s. Kecepatan maksimum berada di stasiun 6 sebesar $0,16 \mathrm{~m} / \mathrm{s}$ pada kedalaman 0,8 meter dan Kecepatan minimum berada pada stasiun 5 di kedalaman 0,8 meter dengan nilai $0,16 \mathrm{~m} / \mathrm{s}$. Sedangkan arus permukaan (Gambar 6) dimana nilai kecepatan arus rata-rata pada permukaan sebesar $0,07 \mathrm{~m} / \mathrm{s}$. Kecepatan arus maksimum berada pada stasiun 2 sebesar $0,152 \mathrm{~m} / \mathrm{s}$ di kedalaman 2 meter dan arus minimum berada di stasiun 12 dengan nilai $0,029 \mathrm{~m} / \mathrm{s}$ pada kedalaman 1 meter. Hasil tersebut dapat menunjukan bahwa nilai kecepatan arus di perairan Mempawah didominasi oleh kecepatan arus dasar.

\section{Kesimpulan}

Terdapat 3 jenis fraksi (butiran) sedimen yang diperoleh yaitu fraksi sedimen pasir, fraksi Lanau dan fraksi Lempung, dimana dari rata-rata persentase fraksi sedimen didominasi oleh fraksi Pasir. Dengan sebaran sebaran jenis sedimen didominasi oleh Tanah liat berpasir dan Tanah liat.

\section{Ucapan Terima Kasih}

Penulis mengucapkan terimakasih kepada orang tua, dosen pembimbing dan penguji skripsi, dan teman-teman seperjuangan atas bimbingan dan dukungannya selalu dalam penyelesaian penelitian ini. Penulis mengucapkan terimakasih kepada Kementrian Riset, Teknologi dan Pendidikan Tinggi Indonesia atas program beasiswa Bidikmisi yang telah mendanai penelitian ini.

\section{Daftar Pustaka}

Agus, F., S. Marwanto, 2006, Penetapan Berat Jenis Partikel Tanah. Sifat Fisik Tanah dan Metode Analisisnya. Balai Besar Litbang Sumberdaya Lahan Pertanian, Badan Penelitian dan Pengembangan Pertanian, Departemen Pertanian.

Hendromi,; Jumarang,M,I.dan Putra, Y.S., 2015,Analisis Karakteristik Fisik Sedimen Pesisir Pantai Sebala Kabupaten Natuna, Ilmu Kelautan Universitas Tanjungpura.

Komar P.D., 1998. Beach Proceses and Sedimentation, 2nd Ed. Prince Hall. New Jersey. 539p.
Pangestu, N.J,; Kushadiwijayanto, A.A. dan Nurrahman, Y, 2020, Studi Batimetri dan Morfologi Muara Sungai Mempawah Kabupaten Mempawah, kalimantan Barat, J.LautKhatulistiwa, (2):29-36.

Solom, J,; Kushadiwijayanto, A.A. dan Nurrahman, Y, 2020, Karakteristik Pasang Surut di Perairan Kuala Mempawah Kalimantan Barat, J.LautKhatulistiwa, (2):17-22.

Triatmodjo, B., 2011, Teknik Pantai, Beta Offset, Yogyakarta.

Triatmodjo, B., 1999, Teknik Pantai, Beta Offset, Yogyakarta.

Yudowati, S, O.; Warsito, A. and Sri, Y, W., 2012, Studi Transpor Sedimen Di Pantai Slamaran Pekalongan, J-Oce, 197-196, FPIK Undip Semarang.

Yugiswara, R, , 2017, Distribusi Sedimen Di Sekitar Muara Sungai Cimandiri Teluk Palabuhan Ratu Sukabumi, Skripsi, Ilmu Dan Teknologi Kelautan Fakultas Perikanan Dan Ilmu Kelautan Institut Pertanian Bogor. 